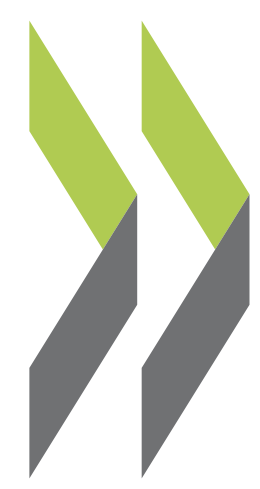

OECD Economics Department Working Papers No. 643

Do Tax Structures Affect Aggregate Economic Growth? Empirical Evidence Jens Matthias Arnold from a Panel of OECD Countries 
Organisation de Coopération et de Développement Économiques

Organisation for Economic Co-operation and Development

14-Oct-2008

ECONOMICS DEPARTMENT

English - Or. English

DO TAX STRUCTURES AFFECT AGGREGATE ECONOMIC GROWTH? EMPIRICAL EVIDENCE FROM A PANEL OF OECD COUNTRIES

ECONOMICS DEPARTMENT WORKING PAPERS No. 643

By Jens Arnold

All OECD Economics Department Working Papers are available on the OECD internet website at www.oecd.org/eco/working_papers

JT03252848

Document complet disponible sur OLIS dans son format d'origine

Complete document available on OLIS in its original format 


\section{ABSTRACT/RESUMÉ \\ Do tax structures affect aggregate economic growth? Empirical evidence from a panel of OECD countries}

This paper examines the relationship between tax structures and economic growth by entering indicators of the tax structure into a set of panel growth regressions for 21 OECD countries, in which both the accumulation of physical and human capital are accounted for. The results of the analysis suggest that income taxes are generally associated with lower economic growth than taxes on consumption and property. More precisely, the findings allow the establishment of a ranking of tax instruments with respect to their relationship to economic growth. Property taxes, and particularly recurrent taxes on immovable property, seem to be the most growth-friendly, followed by consumption taxes and then by personal income taxes. Corporate income taxes appear to have the most negative effect on GDP per capita. These findings suggest that a revenue-neutral growth-oriented tax reform would be to shift part of the revenue base towards recurrent property and consumption taxes and away from income taxes, especially corporate taxes. There is also evidence of a negative relationship between the progressivity of personal income taxes and growth. All of the results are robust to a number of different specifications, including controlling for other determinants of economic growth and instrumenting tax indicators.

JEL classification codes: E62; H21; O47.

Key words: Growth; Tax Structure; Fiscal Policy.

$$
++++
$$

\section{La structure fiscale a-t-elle un effet sur la croissance économique? Évidences empiriques d'un panel de pays de l'OCDE}

Cet article étudie le lien entre la structure de la fiscalité et la croissance économique. L'analyse empirique inclut des indicateurs sur la répartition des taxes dans des équations de croissance pour un panel de 21 pays de l'OCDE, en prenant en compte l'accumulation du capital physique et du capital humain. Les résultats montrent que les impôts sur le revenu sont en général associés avec une croissance plus faible que celle associée aux impôts sur la consommation et sur le patrimoine. Plus précisément, nous établissons un classement des instruments de taxation au regard de leur lien avec la croissance. Les impôts sur le patrimoine, et particulièrement les impôts périodiques sur la propriété immobilière, semblent être les plus favorables à la croissance, suivies immédiatement des impôts sur la consommation. Les impôts sur le revenu des individus semblent être significativement moins favorables, et les impôts sur le revenu des sociétés ont les effets les plus négatifs sur le PIB par tête. Ces résultats suggèrent que les réformes augmentant les impôts sur le patrimoine et la consommation au détriment de ceux sur les entreprises seraient susceptibles d'améliorer les perspectives de croissance économique. L'article trouve également les signes d'une relation négative entre la progressivité des impôts sur le revenu des individus et la croissance. Tous les résultats précédents sont robustes à différentes spécifications, incluant le contrôle des autres déterminants de la croissance économique et l'instrumentation des indicateurs de taxation.

Codes JEL: E62 ; $\mathrm{H21}$; O47.

Mots cle: Croissance ; Structures fiscales ; Politique fiscale.

Copyright OECD, 2008. All rights reserved.

Application for permission to reproduce or translate all, or part of, this material should be made to: Head of Publications Service, OECD, 2 rue André-Pascal, 75775 PARIS CEDEX 16, France. 
TABLE OF CONTENTS

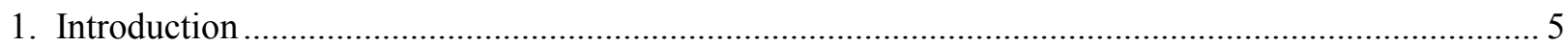

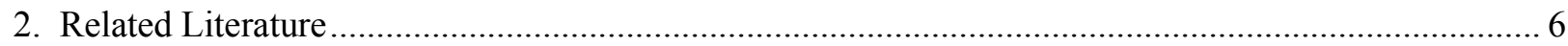

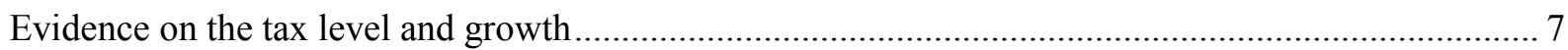

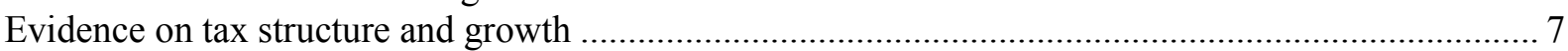

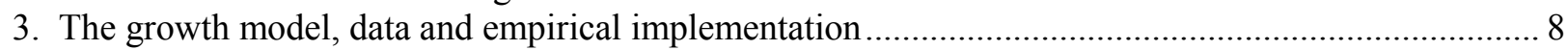

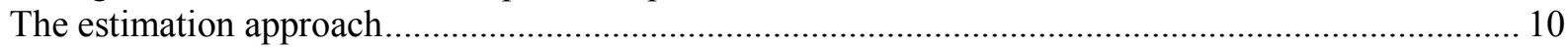

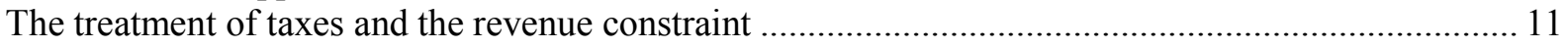

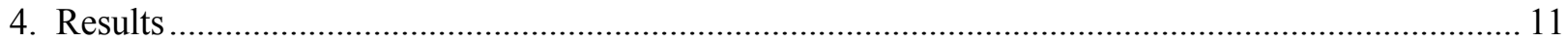

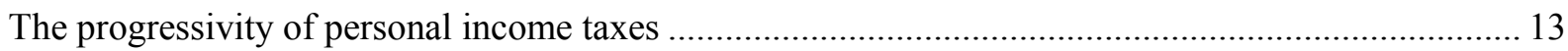

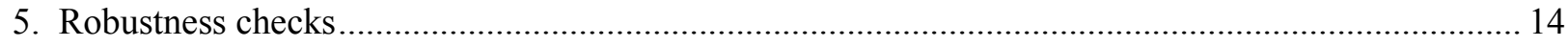

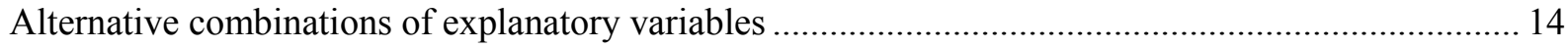

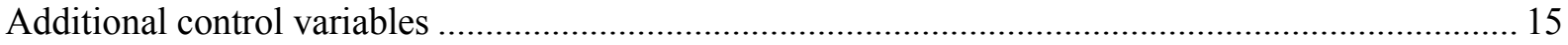

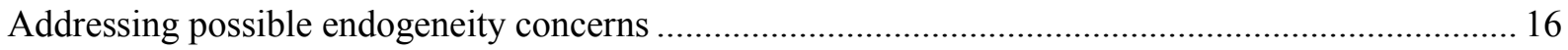

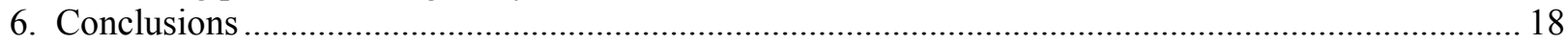

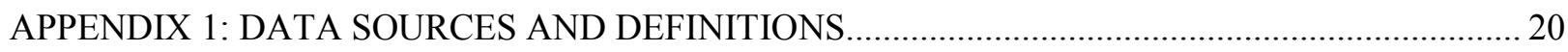

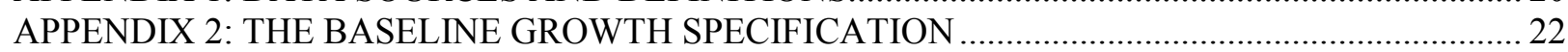

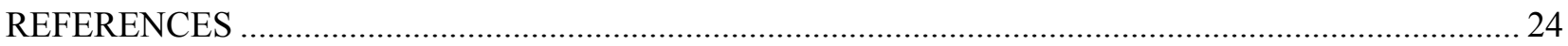


ECO/WKP(2008)51 
ECO/WKP(2008)51

\title{
DO TAX STRUCTURES AFFECT AGGREGATE ECONOMIC GROWTH?
}

\section{EMPIRICAL EVIDENCE FROM A PANEL OF OECD COUNTRIES ${ }^{1}$}

\author{
By Jens Arnold ${ }^{2}$
}

\section{Introduction}

1. Taxes -necessary as they are - distort private decisions, create misallocations of resources and generate dead weight losses. One might therefore conjecture that at least some of these distortions are reflected in aggregate economic performance, and that more distortive tax systems are associated with lower economic growth. Tax systems can be more or less distortive for two reasons: Either because they extract more or less resources from private agents (the tax level), or because they raise a given amount of revenue in more or less distortive ways (the tax structure). The role of the tax structure has been somewhat neglected in the macroeconomic literature on fiscal policy and growth, although the differences in distortions created by different taxes may be substantial, and the negative effect of taxes may ultimately depend on what exactly governments decide to tax. This would suggest a link between economic growth and the way taxes are combined and designed to generate revenues, which will be the subject of this paper.

2. As countries consider reforms to their tax systems, identifying the growth implications of different tax instruments is useful for policy design, regardless of whether or not a change to the overall level of taxes is envisaged. Another reason for focusing on tax structures rather than the overall tax burden is that the overall level of taxes reflects societal choices over the size of the public sector, while the tax structure is first and foremost a tool to implement these choices. Governments may consider changes to the structure of taxes in order to minimise the negative consequences for growth, while maintaining the desired level of public goods and services provided. The aim of this paper is to identify those tax instruments that are associated with the best growth performance in the data. Although the analysis in this paper looks only at the link to growth, it is of course important to acknowledge that growth may not be the only policy objective for tax design.

3. A number of studies have explored the link between the overall level of taxation or of public expenditure and growth across countries, but no consensus about the existence of such a relationship has emerged from this literature. This is not surprising because the overall size of the public sector has two opposite effects: Higher taxes not only mean potentially higher distortions, but usually also higher levels of public expenditure, some of which will foster economic growth.

4. However, the link between tax structures and growth - the focus of this paper - is not subject to this ambiguity. If some tax instruments are indeed more harmful to economic growth than others, then one should be able to detect these patterns in the data, once differences in the level of taxes are controlled for. This paper examines whether there are indeed such patterns visible in a panel of 21 OECD countries over the last 35 years, and whether a stronger reliance on some categories of taxes is associated with stronger growth performance.

1. This work has benefitted greatly from important contributions of Stefano Scarpetta, Åsa Johansson, Giuseppe Nicoletti and and Christopher Heady. The authors would like to thank Jørgen Elmeskov, Jeffrey Owens, Jean-Luc Schneider and Balasz Egert for their valuable comments, as well as Irene Sinha for excellent editorial support. The views expressed in this paper are those of the authors and do not necessarily reflect those of the OECD or its member countries.

2. OECD Economics Department, 2 rue André-Pascal; F-75775 Paris Cedex 16, France, Tel. +33 (0) 14524 87 22, Email jens.arnold@oecd.org. 
5. The evidence presented in this paper is based on a fairly standard empirical model of economic growth that can be derived from both neoclassical and endogenous growth models. It considers the principal determinants of GDP per capita identified in the previous growth literature, including the accumulation of both physical and human capital. Controlling for the overall level of tax revenues, indicators of the tax structure are entered into the growth regressions to evaluate the relationship between tax structures and GDP per capita. One crucial feature of the analysis is that all specifications are estimated under a "government budget constraint", which takes into account that in order to reduce one tax, another must be raised if revenues are to remain unchanged. Taking this simple linear constraint into account allows an evaluation of revenue-neutral changes in the tax structure, and thus a direct comparison between different categories of taxes and their relationship to economic growth.

6. A number of interesting and robust conclusions emerge from the analysis: A stronger reliance on income taxes seems to be associated with significantly lower levels of GDP per capita than the use of taxes on consumption and property. Within income taxes, those on corporate income seem to be associated with lower levels of GDP per capita than personal income taxes. In fact, corporate income taxes appear to be the least attractive choice from the perspective of raising GDP per capita. Comparing only consumption taxes and property taxes, both of which seem superior to income taxes, it is property taxes, and particularly recurrent taxes on immovable property, that appear to be associated with the highest levels of GDP per capita. This ranking of tax instruments according to their "growth-friendliness" is robust to a number of sensitivity checks, including controlling for other possible determinants of growth or changes in the specification, and is confirmed throughout all regressions.

7. Finding the right balance across different tax instruments is of course not the only challenge for tax policy. Within the broad tax categories considered in this paper, taxes can be designed in more or less growth-friendly ways as well. For example, consumption taxes that are broad based may be less distortive than those including many exemptions or reduced rates. While the focus of this paper is largely on a comparison across tax instruments, the results include some evidence suggesting that the degree of progressivity of personal income taxes is negatively associated with GDP per capita. For a treatment of the links between growth and the design of taxes within broad categories, see Johansson et. al. (2008).

8. The remainder of this paper is organised as follows. Section 2 reviews the related literature on fiscal variables and economic growth. Section 3 outlines the growth model and its empirical implementation. Section 4 presents the results on the relationship between tax structure and growth, and the links between taxes and progressivity. Section 5 presents results for a number of variants of the model to check for the robustness of the sign and the size of the estimated tax-to-GDP elasticities, while section 6 concludes. Finally, the annex provides details on data sources and variables used in the analysis.

\section{Related Literature}

9. This paper is related to a large strand of empirical literature trying to explain different patterns of economic growth across countries. Myles (2006) provides a comprehensive survey on this literature and the associated debate on the nature of the convergence of incomes it has triggered. Rather than reviewing the entire growth literature here, this section will focus on a select number of studies that relate growth performance to fiscal variables.

10. Theory predicts that all taxes -with the exception of lump-sum taxes - create distortions, and such distortions could have negative consequences for growth. Easterly (1993) provides empirical evidence for this hypothesis using data for 57 countries. He measures distortions by focusing on deviations from US prices for 151 commodities, and interprets the variance of prices as a measure of how distorted relative prices are in a given economy. The paper shows that the degree of distortions in an economy - whether caused by taxes or by other policies- is indeed negatively correlated with growth. Obviously this falls short 
of demonstrating a link between distortive taxes and growth, but it is nonetheless a powerful demonstration of the potential of price distortions, such as those caused by taxes, to affect economic growth.

\section{Evidence on the tax level and growth}

11. A number of studies have tried to identify a link between the overall level of taxes and growth performance, and overall, this literature has lead to inconclusive results. As an additional complication, even if a robust correlation could be identified in the data, it is far from clear what the direction of causality would be between these two variables. ${ }^{3}$ The first empirical work to include fiscal variable into growth regressions were two studies by Barro $(1989,1991)$, who analysed - among other variables - the ratio of real government consumption expenditure to real GDP as a regressor, and found a significantly negative correlation with growth. Koester and Kormendi (1989) use measures of the average and the marginal tax rate (obtained from a regression of total tax revenues on GDP), but do not distinguish between different tax instruments. In contrast to Barro, they find only limited evidence of a relationship between tax rates and growth.

12. Easterly and Rebelo (1993) use a number of different measures of marginal tax rates to explain growth. Except for one measure, they find no significant correlation between tax rates and growth, and conclude that the link is fragile. Levine and Renelt (1992) also fail to find a robust cross-country relationship between a diverse collection of fiscal policy indicators (though not including variables about the tax structure) and growth. Similarly unstable evidence about this relationship is presented by Slemrod (1995), who finds changing signs depending on the specifcations of parameters and countries considered. For OECD countries alone, he does not find an obvious relationship of either sign between tax rates and GDP per capita. Mendoza et al. (1997) find that their tax variables become insignificant once they control for the initial level of GDP. More recently, Folster and Henrekson (2001) looked at the relationship between growth and the size of government and find a negative relationship between total public expenditure as a share of GDP and growth. Agell et al. (2006) dispute the methodology behind these findings, and find only an unstable and insignificant relationship between the expenditure ratio and growth.

\section{Evidence on tax structure and growth}

13. The findings of the few studies that analysed the link between growth and tax structures rather than tax levels provide somewhat more conclusive answers than the studies that have focused on the level of taxation. Kneller et al. (1999) make a distinction between distortionary taxes on one hand, which they define as taxes on income and property, and so-called non-distortionary taxes on the other hand, which include consumption taxes. Their conclusion is that while the former reduce growth, the latter do not. Similarly, they find that productive government expenditure is beneficial for growth while non-productive public expenditure is not. In a related study, Gemell et al. (2006) use annual data and account for short-run dynamics in a similar way as done in this paper, and confirm the findings of Kneller et al. (1999). Widmalm (2001) examines economic growth between 1965 and 1990 in a cross-section of 23 OECD countries, and finds that the proportion of tax revenues raised from taxing personal incomes is negatively correlated with growth. She also documents a tendency for consumption taxes to be growth-enhancing. Using disaggregate data, Schwellnus and Arnold (2008) and Vartia (2008) document a negative effect of corporate taxes on the productivity of firms and industries, based on a large data sets of firms and

3. A prediction often referred to as "Wagner's law" suggests that as economies grow, the share of public expenditure in gross national product will rise due to increasing demand for services provided by the public sector. Although there may be less doubt about the direction of causality in the relationship between tax structures and growth than in the case of the tax levels, the direction of causality obviously needs to be established using empirical methods and cannot simply be taken for granted. 
industries across OECD countries. Similarly, Lee and Gordon (2005) find a significant negative correlation between statutory corporate tax rates and growth for 70 countries during 1970-1997.

14. Some papers also present evidence on the link between the progressivity of income taxes and growth. One such example is Widmalm (2001). In a similar vein, Padovano and Galli (2002) find a negative influence of marginal effective tax rates and tax progressivity on economic growth in a panel of 25 industrialised countries for 1970 to 1998 . The negative effect of progressivity on entrepreneurial activity is also one of the conclusions of Gentry and Hubbard (2000).

\section{The growth model, data and empirical implementation}

15. In a neoclassical growth model such as Solow (1970), accumulation of labour and capital are the only drivers of economic growth in the long run, with no role for tax or any other policies. Changes in tax structures, however, can nonetheless have a bearing on the long run levels of GDP, with growth effects appearing over a transitional period towards a new equilibrium. The duration of such transitions is in principle unclear, but given considerable adjustment costs of capital stocks or education, it is conceivable that it can take decades to reach a new equilibrium. A very different role for public policies arises, however, in more recent models of endogenous growth like Lucas (1988), in which policies and institutions can have a direct effect on the long run rate of economic growth.

16. Levine and Renelt noted in 1992 that "there does not exist a consensus theoretical framework to guide empirical work on growth". With the literature divided between models of exogenous and endogenous growth, a credible empirical framework should be one that does not force a choice between these two. For this reason, the present analysis is based on an empirical specification that can be derived from both an augmented Solow-Swan-type model and an endogenous growth model a la Lucas (1988). This section only sketches the derivation of the estimation equation here, while referring the technically inclined reader to the full derivation from both kinds of models presented in Arnold et al. (2007).

17. The approach used here starts from a constant-returns-to-scale technology in which output is modelled as a function of inputs of capital, human capital and labour, the efficiency with which they act together, and the level of technology. Generally, such an aggregate production is assumed to be of the Cobb-Douglas type, where production at time $t$ is given by:

$$
Y(t)=K(t)^{\alpha} H(t)^{\beta}(A(t) L(t))^{1-\alpha-\beta}
$$

18. In equation (1) $Y, K, H$ and $L$ are respectively output, physical capital, human capital and labour, $\alpha$ is the partial elasticity of output with respect to physical capital, $\beta$ is the partial elasticity of output with respect to human capital and $A(t)$ is the level of technological and economic efficiency, which for simplicity is assumed to be labour augmenting. ${ }^{4}$ The interpretation of the level of economic and technological efficiency $A(t)$ is that it can be decomposed into two elements: economic efficiency $I(t)$ which can be influenced by institutions and public policies and the level of "exogenous" pure technological progress $\Omega(t)$ (see Cellini et al. 1997 for a similar formulation). This means that $I(t)$ can be written as a function of institutional and policy variables, which will be denoted by the vector $\mathrm{V}(\mathrm{t})$, while $\Omega(t)$ is merely a function of time.

19. Equation (1) can easily be converted into an expression for the steady-state output in intensive form, where GDP per head of the working age population is a function of the investment rate, per capita

4. This formulation makes it conceptually easier to decompose growth into the effects of labour utilisation, labour productivity and capital deepening. 
human capital stocks proxied by the average years of education of the working age population, and the growth rate of the working age population. ${ }^{5}$ If economies were constantly in their steady state, or if one could be satisfied with approximating steady state growth by sufficiently long time averages, such an expression could be directly amenable to the data.

20. The main data source used is the OECD Annual National Accounts data base for output and factor inputs, as well as the OECD Revenue Statistics for information on taxes. The sample includes 21 OECD countries over the period 1971-2004. ${ }^{6}$ Given the limited country coverage of only 21 countries, however, it is desirable to use the maximum degree of information contained in the data. Long time averages over many years or decades, as used in some of the early studies, imply a significant loss of information, and make it difficult to account for unobserved country heterogeneity, which can be a significant concern. Five-year averages have also been used in the literature, on the grounds that they use more information while still purging out short-term cyclical influences. But given the lack of synchronicity in OECD country business cycles, especially in the recent past, it is highly questionable whether cyclical influences are correctly accounted for by averaging over 5 years.

21. For this reason, an attractive alternative option is to use annual data in a fixed effects panel framework and model the transitional dynamics explicitly, rather than accepting the loss of information implied by collapsing the annual data to averages. This implies the need for an estimation framework that is able to account for off-equilibrium dynamics of GDP per capita. For this reason, the present analysis uses an error correction model (ECM), in which the explanatory variables are included both in levels and in first differences to pick up transitional dynamics, in addition to the lagged dependent variable in levels. Thus, assuming a parsimonious one-year lag structure, the logarithmic growth equation in intensive form can be written as follows:

$$
\begin{aligned}
\Delta \ln y_{i, t} & =a_{0, i}-\phi_{i} \ln y_{i, t-1}+a_{1, i} \ln s_{i, t}^{K}+a_{2, i} \ln h_{i, t}-a_{3, i} n_{i, t}+\sum_{j=4}^{m} a_{j, i} \ln V_{i, t}^{j}+\tau_{i} t \\
& +b_{1, i} \Delta \ln s_{i, t}^{K}+b_{2, i} \Delta \ln h_{i, t}+b_{3, i} \Delta n_{i, t}+\sum_{j=4}^{m} b_{j, i} \Delta \ln V_{i, t}^{j}+\varepsilon_{i, t}
\end{aligned}
$$

where $y$ is output per head of the working population, $s^{K}$ is the investment rate, $h$ is the stock of human capital (average years of education), $n$ is the growth rate of the working age population, $a_{0}$ are a set of country fixed effects and $t$ is a function of time. The terms in the second line capture short-term dynamics and $\varepsilon$ is a white noise error term. Equation (2) represents the basic functional form that has been estimated in this paper. ${ }^{7}$

5. Bassanini and Scarpetta (2001) and Arnold et al. (2007) deal in more detail with the formal derivation, and the fact that information on human capital is available only as a stock measure, and how this can be properly accounted for in the equation.

6. The country sample includes: Australia, Austria, Belgium, Canada, Switzerland, West Germany (until 1990), Denmark, Spain, Finland, France, the United Kingdom, Greece, Ireland, Italy, Japan, the Netherlands, Norway, New Zealand, Portugal, Sweden, and the United States. The chosen countries are those with continuous annual series for the variables used in the growth equations over most of the 19712004 period (with the exception of Germany). Appendix 1 provides a detailed description of all variables used.

7. This equation has also been estimated with different lag structures. In general, this was not found to make much of a difference. 
22. Estimates of steady state coefficients as well as of the parameters of the production function can be retrieved on the basis of the estimated coefficients of this equation. For instance, an estimate of the elasticity of steady state output to the investment rate (that is the long-run effect of the investment rate on output) is given by the estimated values of $a_{1} / \Phi$. The regression tables presented in this paper contain the steady state elasticities calculated in this way.

\section{The estimation approach}

23. The next step in the analysis is to find the most appropriate way to estimate equation (2). Given that the equation contains country fixed effects, one possible approach would be to assume that these fixed effects pick up all relevant heterogeneity across countries, and restrict all remaining parameters to be equal across the sample. However, it is a well known fact that OECD economies display different degrees of flexibility. Duval et al. (2007) have documented significant differences across OECD countries with respect to their ability to maintain output close to potential in the aftermath of shocks, which suggests that one should not expect the same adjustment process towards the equilibrium output path across countries. With respect to the long run relationships, however, heterogeneity may be less of a concern. In fact it is quite conceivable that the long-run relationship between tax structures and growth should follow the same economic principles in all countries, even if countries differ in their behaviour around the equilibrium path. Hence, assuming that all slope coefficients are entirely unrelated across countries would represent a loss of efficiency that is unlikely to be warranted. Similarly, in the context of highly integrated OECD economies with access to the same technologies, it is unlikely to expect differences in the long run production function parameters.

24. In this paper, the choice of estimator therefore fell on an intermediate solution, which allows for country-specific convergence paths to the steady state, but assumes that countries display the same longrun relationships between taxes and growth. Such a choice can be implemented by using the Pooled Mean Group (PMG) estimator following Pesaran et al. 1999. More precisely, this approach allows intercepts, the convergence parameter $(\phi),{ }^{8}$ short-run coefficients $\left(b_{s}\right)$ and error variances to differ freely across countries, but imposes restrictions on the long run relationships that lead to more efficient estimates. The principle assumption of this estimator, the hypothesis of cross-country homogeneity of the long-run policy parameters, can be tested explicitly using Hausman specification tests. Indeed, this hypothesis could not be rejected in any of the econometric specifications used here.

25. Finally, in order to allow for unobserved and non-constant country idiosyncrasies, all regressions include country-specific time controls, and both a linear trend and a non-linear specification using indicator variables for 5-year periods have been tried. Non-linear time controls are motivated by the fact that many OECD countries have been affected over the past decades by non-linear patterns of productivity growth, with a slow-down in productivity growth over the late 1970s and 1980s period followed - in some of them - by an acceleration in productivity growth in the 1990s and early 2000s. The non-linear time controls turned out to be the most stable specification, and were retained for the subsequent analysis. Before adding policy variables into equation (2), the baseline specification was subjected to a number of robustness checks (presented in appendix 2), including verifying the stationarity of the residuals, and different lag structures. Using a panel unit root test based on Im et al. (2003), non-stationarity of the residuals was rejected at the $1 \%$ level, and different lag structures had no significant influence on the results obtained.

8. In a theoretical growth model, $\phi$ is a function of population growth $\left(n_{t, t,}\right)$ and technological progress $\left(g_{i, t}\right)$ and thus could vary across countries and over time. For the purpose of the econometric analysis, time homogeneity had to be imposed, but the parameters are allowed to vary across countries. However, country-specific time effects can partly capture differences in the speed of technological progress across countries. 
ECO/WKP(2008)51

\section{The treatment of taxes and the revenue constraint}

26. The focus of the analysis here is on the structure of taxes rather than their level. However, given the considerable differences in the overall tax level across countries, not controlling for these differences could give rise to spurious correlations. For this reason, all regressions contain the tax level, expressed as the share of total tax revenues in GDP, as a control variable. ${ }^{9}$ As regards information on tax structures, the basic source of information is based on the revenue shares of each of the tax instruments, measuring the extent to which different countries make recourse to a range of tax instruments to raise tax revenues.

27. Once the tax level is controlled for, however, the analysis faces a similar problem to what Kneller et al. (1999) call the "government budget constraint": Since the sum of revenues across tax instruments is controlled for in the regression, any change in revenues from a given tax instrument will affect the amount of taxes that need to be raised from the remaining instruments to maintain the same overall revenues. The resulting econometric problem is that entering the share of revenues in total tax revenues for all tax instruments simultaneously into a growth regression, while at the same time controlling for the overall tax level, would make the equation over-identified. In more intuitive words, it is not possible to have a growth effect from one tax instrument without a simultaneous effect from the other (or at least one other when more than two tax instruments are distinguished), if total revenues are to remain constant.

28. Such trade-offs at constant revenues can, however, be properly accounted for by adopting the estimation approach suggested by Kneller et al. (1999) and Gemmell et al. (2006) who suggest estimating the growth regressions subject to an implicit constraint. In the present case, this constraint is simply the fact that the sum of the revenue shares of different tax instruments is one. Failing to account for this constraint and the implicit financing assumption built into the regressions due to the linear relationship between fiscal variables is likely introduce an estimation bias (Bleaney et al. 2001).

29. It is possible to account for the constraint explicitly by omitting one if its elements at a time, with the interpretation being that the omitted element is left free to close the system. In other words, the omitted tax instrument can be thought of as the residual that would be reduced if one of those included in the specification are raised. This approach is very convenient, because it allows evaluating different tax policy reforms under the assumption of revenue neutrality, while explicitly modelling which tax would be reduced as another one is raised. For example, one can drop the category "Consumption and Property Taxes" from the estimation, and interpret the coefficient on "Income Taxes" as the long-run effects on GDP per capita that would result if a country were to rely more strongly on the latter, while adjusting the level of consumption and property taxes so as to keep total revenues constant.

\section{Results}

30. Table 1 presents the basic results of adding tax indicators into the growth regressions. The bottom line of the table indicates which tax is omitted in each regression, and thus assumed to be absorbing changes in the others that are included in the regression to maintain revenue neutrality. While the estimations find a consistently negative coefficient for the overall tax burden, it is difficult to give this a precise interpretation without more detailed attention to the different public expenditures that are financed with the corresponding tax revenues. As a result, it would be premature to draw any policy conclusions from the sign of this coefficient, beyond the fact that it is a necessary control variable that will be retained throughout the subsequent analysis.

9. Note that even after controlling for differences in tax levels, one cannot rule out with certainty a residual correlation between levels and a particular reliance on certain tax instruments. 
31. A first estimation compares income taxes versus taxes on consumption and property. More precisely, column (1) evaluates the impact on long-run GDP per capita of a hypothetical shift towards the broad category of income taxes, if such a reform were financed by a reduction of consumption and property taxes. The estimated coefficient suggests negative effects on GDP per capita, and the effect is highly significant. Column (3) turns this reasoning around by asking the same question from the opposite side. It shows that a stronger reliance on consumption and property taxes, with a resulting reduction in income taxes, would enhance GDP per capita. This is one of the basic findings of this paper: Income taxes seem to be associated with lower GDP per capita than taxes on consumption and property.

32. In Column (2), income taxes are broken down into personal income taxes and corporate income taxes, with consumption and property taxes once again as the residual adjustment factor. Both personal and corporate income taxes have a significant negative effect, meaning that both of them reduce growth relative to consumption and property taxes. However, the effect of corporate income taxes is significantly more negative than that of personal income taxes, with a t-test suggesting that the difference between the two is highly significant at the $1 \%$ level. Thus, a policy reform seeking to replace revenues from consumption and property taxes by either personal or corporate income taxes would reduce long-run GDP per capita, but the reduction would be considerably stronger if the choice fell on corporate income taxes.

33. Column (4) makes a distinction between consumption taxes and property taxes, with residual adjustment falling on income taxes. Both consumption taxes and property taxes appear more conducive to high long-run levels of GDP per capita than income taxes. In addition, switching to property taxation seems to be more growth-enhancing than consumption taxes. Property taxes, however, are still a heterogeneous group, and a further distinction between recurrent taxes on immovable property and other kinds of property taxes could help identify the driving element of this relatively growth-friendly tax instrument. ${ }^{10}$ For this reason, Column (5) adds a distinction between recurrent taxes on immovable property and other property taxes. These results show that it is the recurrent taxes on immovable property that appear to be particularly conducive to economic growth, and they appear to be driving the performance of property taxes in the regression analysis. The coefficient is highly positive, demonstrating that these taxes are significantly better for growth than income taxes, which is the omitted category. ${ }^{11}$ The difference with respect to the coefficient on consumption taxes is significant at the $5 \%$ level. Other property taxes, in contrast, have a non-significant coefficient.

10. Other recurrent property taxes (category 4600, a very small position that makes up less than $0.01 \%$ of property taxes on average) have also been grouped with property taxes on immovable property.

11. There is further empirical evidence that within the group of recurrent taxes on immovable property, it is particularly the part that is raised from households (category 4110) as opposed to the part raised from firms that is the most growth-friendly. An alternative grouping of property taxes with a distinction of taxes levied on households versus all other property taxes showed a particularly high positive coefficient for the former tax instrument. Due to incomplete reporting, however, this distinction is only possible for a significantly smaller subsample, with the number of observations dropping to around half of the sample in table 2 . Given their lack of comparability, these regression results are not reported. 
Table 1. Growth regressions including taxes ${ }^{1}$

The estimated empirical model is:

$\Delta \ln y_{\text {it }}=-\Phi_{\mathrm{i}}\left(\ln y_{\mathrm{it}-1}-\theta_{1} \ln s^{\mathrm{k}}{ }_{\mathrm{it}}{ }^{-} \theta_{2} \ln h_{\mathrm{it}}+\theta_{3} n_{\mathrm{it}}+\sum \theta_{\mathrm{j}} \ln V^{\mathrm{j}}{ }_{\mathrm{it}}-\mathrm{a}_{\mathrm{it}}\right)+\mathrm{b}_{1 \mathrm{i}} \Delta \ln s^{\mathrm{k}}{ }_{\mathrm{it}}+\mathrm{b}_{2 \mathrm{i}} \Delta \ln h_{\mathrm{it}}+\mathrm{b}_{3 i} \Delta n_{\mathrm{it}}+\sum \mathrm{b}_{\mathrm{ji}} \Delta \ln V^{\mathrm{j}}{ }_{\mathrm{it}}+\varepsilon_{\mathrm{it}}$

\begin{tabular}{|c|c|c|c|c|c|}
\hline Dependent Variable: Log GDP p.c. & (1) & (2) & (3) & (4) & (5) \\
\hline \multicolumn{6}{|l|}{ Baseline Model } \\
\hline Physical Capital & $\begin{array}{l}0.18^{* * *} \\
(0.05)\end{array}$ & $\begin{array}{l}0.25^{* * *} \\
(0.05)\end{array}$ & $\begin{array}{l}0.18^{* * *} \\
(0.05)\end{array}$ & $\begin{array}{l}0.16 \text { *** } \\
(0.05)\end{array}$ & $\begin{array}{r}0.21 \\
(0.45)\end{array}$ \\
\hline Human Capital & $\begin{array}{l}1.19 * * * \\
(0.13)\end{array}$ & $\begin{array}{l}1.30^{* * *} \\
(0.12)\end{array}$ & $\begin{array}{l}1.18^{* * *} \\
(0.13)\end{array}$ & $\begin{array}{l}1.40^{* * *} \\
(0.11)^{*}\end{array}$ & $\begin{array}{l}1.57^{\star * \star} \\
(0.11)\end{array}$ \\
\hline Population Growth & $\begin{array}{l}-0.08 * * * \\
(0.01)\end{array}$ & $\begin{array}{l}-0.08^{* * *} \\
(0.01)\end{array}$ & $\begin{array}{l}-0.07^{* * *} \\
(0.01)\end{array}$ & $\begin{array}{l}-0.07^{* * *} \\
(0.01)\end{array}$ & $\begin{array}{l}-0.07^{* * *} \\
(0.01)\end{array}$ \\
\hline \multicolumn{6}{|l|}{ Control variable } \\
\hline $\begin{array}{l}\text { Overall Tax Burden } \\
\text { (Total revenues / GDP) }\end{array}$ & $\begin{array}{l}-0.27^{* * *} \\
(0.05)\end{array}$ & $\begin{array}{l}-0.24^{* * *} \\
(0.05)\end{array}$ & $\begin{array}{l}-0.26 \text { *** } \\
(0.05)\end{array}$ & $\begin{array}{l}-0.222^{* * *} \\
(0.04)\end{array}$ & $\begin{array}{l}-0.144^{* * *} \\
(0.04)\end{array}$ \\
\hline \multicolumn{6}{|l|}{ Tax structure variables } \\
\hline Income Taxes & $\begin{array}{l}-0.98 * * * \\
(0.20)\end{array}$ & & & & \\
\hline Personal Income Taxes & & $\begin{array}{l}-1.13^{* * *} \\
(0.19)\end{array}$ & & & \\
\hline Corporate Income Taxes & & $\begin{array}{l}-2.011^{* * *} \\
(0.32)\end{array}$ & & & \\
\hline Consumption \& Property Taxes & & & $\begin{array}{l}0.93^{* * *} \\
(0.20)\end{array}$ & & \\
\hline $\begin{array}{l}\text { Consumption taxes } \\
\text { (excl. property taxes) }\end{array}$ & & & & $\begin{array}{l}0.74^{* * *} \\
(0.18)\end{array}$ & $\begin{array}{l}0.72 \text { *** } \\
(0.19)\end{array}$ \\
\hline Property taxes & & & & $\begin{array}{l}1.45^{* * *} \\
(0.43)\end{array}$ & \\
\hline Property taxes: Recurrent Taxes on Immovable Property & & & & & $\begin{array}{l}2.47^{* \star \star} \\
(0.84)\end{array}$ \\
\hline Property taxes: Other property taxes & & & & & $\begin{array}{r}-0.34 \\
(0.51) \\
\end{array}$ \\
\hline Observations & 696 & 675 & 696 & 696 & 698 \\
\hline Revenue-neutrality achieved by adjusting & $\begin{array}{l}\text { ons. \& } \\
\text { op. Taxes }\end{array}$ & $\begin{array}{l}\text { Oons. \& } \\
\text { rop. Taxes }\end{array}$ & $\begin{array}{l}\text { Income } \\
\text { Taxes }\end{array}$ & $\begin{array}{l}\text { Income } \\
\text { Taxes }\end{array}$ & $\begin{array}{l}\text { ncome } \\
\text {-axes }\end{array}$ \\
\hline
\end{tabular}

1. In the estimated model, $y$ refers to output per capita, $s_{k}$ to the investment rate into physical capital, $h$ to human capital, $n$ to the population growth rate, respectively. The vector $V$ contains a set of policy variables. All equations include short-run dynamics, country-specific intercepts and country-specific time controls. Standard errors are in brackets. *: significant at $10 \%$ level; ${ }^{* *}$ at $5 \%$ level; ${ }^{* * *}$ at $1 \%$ level.

34. Bringing together the results in Columns (1) to (5), a relative tax and growth ranking can be established between the four tax instruments considered here: Corporate income taxes appear to have the most negative consequences for GDP per capita, followed by personal income taxes. Consumption taxes seem to have considerably less negative effects on economic performance, while property taxes, and in particular recurrent taxes on immovable property appear to be the least harmful.

\section{The progressivity of personal income taxes}

35. A particular characteristic of personal income taxes is that they are often applied at progressive rates. While progressivity can provide some degree of risk-sharing between entrepreneurs and fiscal authorities because potential losses can be written off against other income, it also discourages risk-taking. 
This is because progressive taxes reduce the post-tax income differential between the cases where an entrepreneur is successful and the alternative case of a business failure. Gentry and Hubbard (2000) argue that since the extra tax that applies to high profits is greater than the tax saving produced by losses, this effectively reduces the strength of the risk-sharing effect.

36. This hypothesis has been tested by creating a simple progressivity measure based on the relationship between marginal and average tax rates for an average production worker wage. ${ }^{12}$ The results in Table 2 show that a stronger progressivity of personal income taxes seems to be associated with lower long-run GDP per capita, regardless of whether the tax burden or the extent to which a country relies on personal income taxes (this time including only those taxes to which progressive schedules are typically applied) are controlled for or not.

Table 2. Progressivity of personal income taxes ${ }^{1}$

\begin{tabular}{|c|c|c|c|}
\hline Dependent Variable: Log GDP p.c. & $(1)$ & $(2)$ & (3) \\
\hline \multicolumn{4}{|l|}{ Baseline Model } \\
\hline Physical Capital & $\begin{array}{l}0.26^{* * *} \\
(0.03)\end{array}$ & $\begin{array}{l}0.21^{* * *} \\
(0.04)\end{array}$ & $\begin{array}{l}0.36^{* * *} \\
(0.02)\end{array}$ \\
\hline Human Capital & $\begin{array}{l}2.2^{* * *} \\
(0.14)\end{array}$ & $\begin{array}{l}2.1^{* * *} \\
(0.13)\end{array}$ & $\begin{array}{l}2.78^{* * *} \\
(0.07)\end{array}$ \\
\hline Population Growth & $\begin{array}{l}-0.11^{* * *} \\
(0.01)\end{array}$ & $\begin{array}{l}-0.14 \text { *** } \\
(0.01)\end{array}$ & $\begin{array}{l}-0.06^{* * *} \\
(0.01)\end{array}$ \\
\hline \multicolumn{4}{|l|}{ Control variable } \\
\hline $\begin{array}{l}\text { Overall Tax Burden } \\
\text { (Total revenues / GDP) }\end{array}$ & & $\begin{array}{l}-0.38^{* * *} \\
(0.06)\end{array}$ & $\begin{array}{l}-0.14^{* * *} \\
(0.03)\end{array}$ \\
\hline \multicolumn{4}{|l|}{ Tax structure variables } \\
\hline $\begin{array}{l}\text { Share of Personal Income Taxes } \\
\text { (excl. SSC, payroll taxes) }\end{array}$ & & & $\begin{array}{l}-0.20^{* * *} \\
(0.05)\end{array}$ \\
\hline Progressivity of Income Taxes & $\begin{array}{l}-0.19 * * \\
(0.08)\end{array}$ & $\begin{array}{l}-0.11^{* *} \\
(0.05)\end{array}$ & $\begin{array}{l}-0.16^{* * *} \\
(0.04)\end{array}$ \\
\hline Observations & 397 & 397 & 392 \\
\hline
\end{tabular}

\section{Robustness checks}

\section{Alternative combinations of explanatory variables}

37. With four different tax instruments to be evaluated and one omitted at a time, it is clear that there are more possible combinations to be estimated than the regressions presented in Table 1. While no additional insights are to be expected from different combinations of the regressors, it would nonetheless increase the confidence in the above results to know that the choice of a particular regression set up is not central to the ranking of tax instruments in terms of their effects on long-run GDP per capita levels. As a

12. The progressivity measure is defined as 1 - (100- marginal tax rate)/(100-average tax rate), evaluated at the average production worker wage. The measure is increasing in the gap between the marginal and the average tax rate. 
robustness check, all of these regressions have been estimated, and they confirm the rank ordering of the four tax instruments as set out above (Table 3 ).

Table 3. Additional results using tax indicators ${ }^{1}$

The estimated empirical model is:

$\Delta \ln y_{\mathrm{it}}=-\Phi_{\mathrm{i}}\left(\ln y_{\mathrm{it}-1}-\theta_{1} \ln s^{\mathrm{k}}{ }_{\mathrm{it}}-\theta_{2} \ln h_{\mathrm{it}}+\theta_{3} n_{\mathrm{it}}+\sum \theta_{\mathrm{j}} \ln V_{\mathrm{it}}^{\mathrm{j}}-\mathrm{a}_{\mathrm{it}}\right)+\mathrm{b}_{1 \mathrm{i}} \Delta \ln s^{\mathrm{k}}{ }_{\mathrm{it}}+\mathrm{b}_{2 \mathrm{i}} \Delta \ln h_{\mathrm{it}}+\mathrm{b}_{3 \mathrm{i}} \Delta n_{\mathrm{it}}+\sum \mathrm{b}_{\mathrm{ji}} \Delta \ln V_{\mathrm{it}}^{\mathrm{j}}+\varepsilon_{\mathrm{it}}$

\begin{tabular}{|c|c|c|c|c|}
\hline Dependent Variable: Log GDP p.c. & (1) & $(2)$ & (3) & (4) \\
\hline \multicolumn{5}{|l|}{ Baseline Model } \\
\hline Physical Capital & $\begin{array}{l}0.22 \text { *** } \\
(0.05)\end{array}$ & $\begin{array}{l}0.20 \\
(0.05)\end{array}$ & $\begin{array}{l}0.21^{* * *} \\
(0.05)\end{array}$ & $\begin{array}{l}0.222^{* * *} \\
(0.05)\end{array}$ \\
\hline Human Capital & $\begin{array}{l}1.54^{* * *} \\
(0.12)\end{array}$ & $\begin{array}{l}1.58^{* * *} \\
(0.11)\end{array}$ & $\begin{array}{l}1.49^{\star \star *} \\
(0.12)\end{array}$ & $\begin{array}{l}1.52^{* * *} \\
(0.12)\end{array}$ \\
\hline Population Growth & $\begin{array}{l}-0.07^{* * *} \\
(0.01)\end{array}$ & $\begin{array}{l}-0.07^{* * *} \\
(0.01)\end{array}$ & $\begin{array}{l}-0.07^{* * *} \\
(0.01)\end{array}$ & $\begin{array}{l}-0.08^{* * *} \\
(0.01)\end{array}$ \\
\hline \multicolumn{5}{|l|}{ Control variable } \\
\hline $\begin{array}{l}\text { Overall Tax Burden } \\
\text { (Total revenues / GDP) }\end{array}$ & $\begin{array}{l}-0.24^{* * *} \\
(0.05)\end{array}$ & $\begin{array}{l}-0.25^{* * *} \\
(0.04)\end{array}$ & $\begin{array}{l}-0.25^{* * *} \\
(0.05)\end{array}$ & $\begin{array}{l}-0.25^{* * *} \\
(0.04)\end{array}$ \\
\hline \multicolumn{5}{|l|}{ Tax structure variables } \\
\hline Personal Income Taxes & & $\begin{array}{l}1.01^{* * *} \\
(0.21)^{* *}\end{array}$ & $\begin{array}{l}-0.96 * * * \\
(0.18)\end{array}$ & $\begin{array}{l}-1.35^{* * *} \\
(0.34)\end{array}$ \\
\hline Corporate Income Taxes & $\begin{array}{l}-1.18^{* * *} \\
(0.22)\end{array}$ & & $\begin{array}{l}-2.04^{* \star *} \\
(0.30)\end{array}$ & $\begin{array}{l}-2.40^{* * *} \\
(0.43)\end{array}$ \\
\hline $\begin{array}{l}\text { Consumption taxes } \\
\text { (excl. property taxes) }\end{array}$ & $\begin{array}{l}0.92^{* * *} \\
(0.18)\end{array}$ & $\begin{array}{l}2.16^{* * *} \\
(0.31)\end{array}$ & & $\begin{array}{l}-0.21 \\
(0.34)\end{array}$ \\
\hline Property taxes & $\begin{array}{l}1.55^{* * *} \\
(0.38)\end{array}$ & $\begin{array}{l}2.71^{\star * *} \\
(0.47)\end{array}$ & $\begin{array}{l}0.71 \\
(0.37)\end{array}$ & \\
\hline
\end{tabular}

\begin{tabular}{lllll}
\hline Observations & 678 & 675 & 675 & 675 \\
\hline \multirow{2}{*}{ Revenue-neutrality achieved by adjusting } & Personal & Corporate & Cons. & Property \\
& $\begin{array}{l}\text { Income } \\
\text { Taxes }\end{array}$ & $\begin{array}{l}\text { Income } \\
\text { Taxes }\end{array}$ & $\begin{array}{l}\text { Taxes } \\
\text { Taxes }\end{array}$ \\
\hline
\end{tabular}

1. In the estimated model, $y$ refers to output per capita, $s_{k}$ to the investment rate into physical capital, $h$ to human capital, $n$ to the population growth rate, respectively. The vector $V$ contains a set of policy variables. All equations include short-run dynamics, country-specific intercepts and country-specific time controls. Standard errors are in brackets. *: significant at $10 \%$ level; ${ }^{* *}$ at $5 \%$ level; ${ }^{* *}$ at $1 \%$ level.

\section{Additional control variables}

38. Beyond taxes, a number of other variables have been identified as driving the developments of GDP per capita in previous studies, both in the context of OECD studies and in academic research. Here, the variables considered are inflation, the volatility (or predictability) of inflation, openness to international trade and research and development (R\&D). These four variables have been included into the regressions in addition to the tax indicators, in order to evaluate the robustness of the findings on taxes once these other factors are accounted for. The econometric technique used here, the PMG estimator, relies on a complex non-linear maximum likelihood algorithm, and therefore puts constraints on the number of explanatory variables that can be included in any given regression. If the number of explanatory variables is too large, the algorithm will simply not converge. As a result, this robustness check had to be limited to 
the distinction between the two broader groups of taxes, i.e. comparing income taxes to taxes on consumption and property. These results are presented in Table 4.

Table 4. Controlling for additional factors ${ }^{1}$

The estimated empirical model is:

$\Delta \ln y_{\text {it }}=-\Phi_{\mathrm{i}}\left(\ln y_{\mathrm{it}-1}-\theta_{1} \ln s^{\mathrm{K}}{ }_{\mathrm{it}}-\theta_{2} \ln h_{\mathrm{it}}+\theta_{3} n_{\mathrm{it}}+\sum \theta_{\mathrm{j}} \ln V^{\mathrm{j}}{ }_{\mathrm{it}}-\mathrm{a}_{\mathrm{it}}\right)+\mathrm{b}_{1 \mathrm{i}} \Delta \ln s^{\mathrm{k}}{ }_{\mathrm{it}}+\mathrm{b}_{2 \mathrm{i}} \Delta \ln h_{\mathrm{it}}+\mathrm{b}_{3 \mathrm{i}} \Delta n_{\mathrm{it}}+\sum \mathrm{b}_{\mathrm{ji}} \Delta \ln V_{\mathrm{it}}^{\mathrm{J}}+\varepsilon_{\mathrm{it}}$

\begin{tabular}{|c|c|c|c|c|c|c|c|c|}
\hline Dependent Variable: Log GDP p.c. & (1) & $(2)$ & (3) & $(4)$ & $(5)$ & (6) & (7) & (8) \\
\hline Physical Capital & $\begin{array}{l}0.25^{* * *} \\
(0.05)\end{array}$ & $\begin{array}{l}0.24^{* * *} \\
(0.05)\end{array}$ & $\begin{array}{l}0.22 \\
(0.06)\end{array}$ & $\begin{array}{l}0.22 \\
(0.06)\end{array}$ & $\begin{array}{l}0.30 \text { *** } \\
(0.04)\end{array}$ & $\begin{array}{l}0.30 \text { *** } \\
(0.04)\end{array}$ & $\begin{array}{l}0.24^{* * *} \\
(0.04)\end{array}$ & $\begin{array}{l}0.22 \text { *** } \\
(0.04)\end{array}$ \\
\hline Human Capital & $\begin{array}{l}1.61 \\
(0.15)\end{array}$ & $\begin{array}{l}1.63^{\text {*** }} \\
(0.16)\end{array}$ & $\begin{array}{l}1.22 \text { *** } \\
(0.20)\end{array}$ & $\begin{array}{l}1.23^{\text {***}} \\
(0.20)\end{array}$ & $\begin{array}{l}0.77^{* * *} \\
(0.16)\end{array}$ & $\begin{array}{l}0.78^{\text {*** }} \\
(0.17)\end{array}$ & $\begin{array}{l}1.53^{\text {***}} \\
(0.15)\end{array}$ & $\begin{array}{l}1.56 \text { *** } \\
(0.15)\end{array}$ \\
\hline Population Growth & $\begin{array}{l}-0.09^{* * *} \\
(0.01)\end{array}$ & $\begin{array}{l}-0.09^{* * *} \\
(0.01)\end{array}$ & $\begin{array}{l}-0.11^{\text {*** }} \\
(0.02)\end{array}$ & $\begin{array}{l}-0.11^{\text {*** }} \\
(0.02)\end{array}$ & $\begin{array}{l}-0.05^{* * *} \\
(0.01)\end{array}$ & $\begin{array}{l}-0.06^{\text {*** }} \\
(0.01)\end{array}$ & $\begin{array}{l}-0.14^{* * *} \\
(0.01)\end{array}$ & $\begin{array}{l}-0.14^{\text {*** }} \\
(0.01)\end{array}$ \\
\hline $\begin{array}{l}\text { Overall Tax Burden } \\
\text { (Total revenues / GDP) }\end{array}$ & $\begin{array}{l}-0.36^{* * *} \\
(0.06)\end{array}$ & $\begin{array}{l}-0.36^{* * *} \\
(0.06)\end{array}$ & $\begin{array}{l}-0.42^{* * *} \\
(0.07)\end{array}$ & $\begin{array}{l}-0.43^{* * *} \\
(0.07)\end{array}$ & $\begin{array}{l}-0.28 * * * \\
(0.04)\end{array}$ & $\begin{array}{l}-0.29 * * * \\
(0.05)\end{array}$ & $\begin{array}{l}-0.42^{* * *} \\
(0.04)\end{array}$ & $\begin{array}{l}-0.41^{* * *} \\
(0.04)\end{array}$ \\
\hline Consumption \& Property Taxes & $\begin{array}{l}0.90^{* * *} \\
(0.20)\end{array}$ & & $\begin{array}{l}0.94^{* * *} \\
(0.24)\end{array}$ & & $\begin{array}{l}0.60^{* * *} \\
(0.15)\end{array}$ & & $\begin{array}{l}0.25^{* *} \\
(0.12)\end{array}$ & \\
\hline Income Taxes & & $\begin{array}{l}-0.93^{* * *} \\
(0.20)\end{array}$ & & $\begin{array}{l}-0.96 \text { *** } \\
(0.25)\end{array}$ & & $\begin{array}{l}-0.65^{* * *} \\
(0.15)\end{array}$ & & $\begin{array}{l}-0.28^{* *} \\
(0.12)\end{array}$ \\
\hline Inflation & $\begin{array}{l}-2.30^{\star * *} \\
(0.42)\end{array}$ & $\begin{array}{l}-2.32^{* * *} \\
(0.42)\end{array}$ & $\begin{array}{l}-2.48^{* \star *} \\
(0.53)\end{array}$ & $\begin{array}{l}-2.48^{\text {***}} \\
(0.53)\end{array}$ & $\begin{array}{l}-0.87^{\text {***}} \\
(0.26)\end{array}$ & $\begin{array}{l}-0.90^{* * *} \\
(0.27)\end{array}$ & $\begin{array}{l}-1.15^{* * *} \\
(0.29)\end{array}$ & $\begin{array}{l}-1.07^{\star \star \star} \\
(0.28)\end{array}$ \\
\hline Inflation volatility & & & $\begin{array}{l}-4.77^{* * *} \\
(1.01)\end{array}$ & $\begin{array}{l}-4.66^{* * *} \\
(1.00)\end{array}$ & & & & \\
\hline Trade Openness & & & & & $\begin{array}{l}0.37^{\text {***}} \\
(0.05)\end{array}$ & $\begin{array}{l}0.37^{\text {***}} \\
(0.05)\end{array}$ & & \\
\hline Research \& Development & & & & & & & $\begin{array}{l}0.18^{* * *} \\
(0.04)\end{array}$ & $\begin{array}{l}0.16^{* * *} \\
(0.04)\end{array}$ \\
\hline $\begin{array}{l}\text { Revenue-neutrality achieved by } \\
\text { adjusting }\end{array}$ & Income Taxes & $\begin{array}{l}\text { Cons. \& Prop. } \\
\text { Taxes }\end{array}$ & Income Taxes & $\begin{array}{l}\text { Cons. \& Prop. } \\
\text { Taxes }\end{array}$ & Income Taxes & $\begin{array}{l}\text { Cons. \& Prop. } \\
\text { Taxes }\end{array}$ & Income Taxes & $\begin{array}{l}\text { Cons. \& Prop. } \\
\text { Taxes }\end{array}$ \\
\hline
\end{tabular}

1. In the estimated model, y refers to output per capita, sk to the investment rate into physical capital, $\mathrm{h}$ to human capital, $\mathrm{n}$ to the population growth rate, respectively. The vector $\mathrm{V}$ contains a set of policy variables and covariates. All equations include short-run dynamics, country-specific intercepts and countryspecific time controls. Standard errors are in brackets. *: significant at $10 \%$ level; ${ }^{* *}$ at $5 \%$ level; ${ }^{* *}$ at $1 \%$ level.

39. Columns (1) and (2) control for inflation as additional covariates. In line with the previous findings, consumption and property have a positive coefficient when income taxes are the omitted element, while income taxes have a negative coefficient when consumption and property taxes are omitted. Inflation is estimated to have a significant negative effect on GDP per capita in all cases. Inflation is retained as a regressor in the remaining estimations, and Columns (3) and (4) control additionally for the volatility of inflation. A high volatility of inflation rates will make inflation difficult to predict, and may hence put a strain on the efficiency of the economy. This conjecture is confirmed by the results obtained in Columns (3) and (4), in which the estimated coefficient on the volatility of inflation (measured by its standard deviation), is significant and negative. The comparison between the tax categories, however, remains unchanged. Trade openness has also been identified as a determinant of growth, and indeed the estimations in Columns (5) and (6) suggest that greater openness to trade enhances GDP per capita. Again, the results on taxes are not affected by this additional explanatory variable. The final set of estimations in Columns (7) and (8) add expenditures for $R \& D$ into the regressions. It should be noted that this information is available only for a subset of the observations, resulting in a considerable drop in the number of observations. In this set of estimations, the findings on the tax indicators remain unchanged as well.

\section{Addressing possible endogeneity concerns}

40. In an additional set of robustness checks, an attempt is made to control for the fact that most of the tax indicators used in the analysis are derived from Revenue Statistics and from National Accounts. 
This could lead to an endogeneity bias insofar as tax revenues increase in expansions and declines in recessions, even though short-run dynamics are accounted for in the regressions. While neither consumption nor property taxes are likely to react strongly to the cycle, the income tax base may well be affected by cyclical factors. Although the short-term dynamics included in the estimation procedure are meant to pick up precisely this kind of cyclical fluctuations, robustness checks have been run in which the tax indicators are examined for systematic correlation with the business cycle and purged of any cyclical influences. Doing so demands slight changes in the estimation method. Given that any treatment of the original data for such purposes implies that the accounting identities such as Equation 4 exploited previously will no longer hold, a slightly different set of tax indicators had to be used for this exercise, and the results can no longer be interpreted as revenue-neutral thought experiments as before.

41. In Table 5, the income tax indicators have been purged of all possible correlations with the business cycle, by regressing them on the output gap ${ }^{13}$ in a first stage and using the residuals of these regressions instead of the actual tax variable in the growth regressions. In the first stage regressions, only corporate income taxes are found to be related to expansions and declines of GDP. This comes as no surprise, given that corporate profits are likely to display a stronger correlation with the business cycle than labour income.

42. In order to assess the robustness of the previous findings and to check to what extent regressors expressing short-run dynamics were able to, by themselves, separate short fluctuations from long-run effects, Column (1) repeats the evaluation of income taxes versus consumption and property taxes using the transformed income tax regressor, purged of cyclical influences. As in the main results, the coefficient on the reliance on income taxes is negative and highly significant. In Column (2), an additional explanatory variable is added to distinguish between personal and corporate income taxes. In order to distinguish between these sources of revenues while maintaining income taxes as a regressor, the additional explanatory variable is defined as the share of corporate income taxes in total income taxes (purged of business cycle influences). The estimated coefficient is again negative and significant, confirming the previous findings that corporate taxes seem to hamper growth more than personal income taxes.

43. Column (3) of Table 5, shows an additional robustness check regarding the only variable that displays a significant correlation to the business cycle, the share of corporate taxes in income taxes. In this regression, instead of purging it of the correlation with the output gap, the variable has been instrumented using four own lags as instruments. In this specification, the coefficient on the variable is lower, but remains negative and significant at the $5 \%$ level.

44. A final specification has been estimated in Column (4), using tax rates rather than revenue information. Given that tax rates are usually not changed very frequently, these are unlikely to have any relation to the business cycle. This regression contains a first indicator drawn from statutory average tax rates on corporate profits and personal income (labelled Income Tax Rate). This indicator is the ratio of the corporate tax rate and the weighted average of personal and corporate income tax rate - with weights being the average shares of the respective tax bases in each country's GDP. ${ }^{14}$ As a second explanatory variable, the statutory corporate tax rate (relative to the income tax rate as defined above) is included. Both coefficients are significant and negative, but the coefficient on the corporate tax rate is considerably more negative, again confirming previous findings.

13. These regressions include first and second lags of the output gap and linear as well as quadratic terms.

14 It should be stressed that both the statutory corporate tax rate and the personal income tax rates, while less endogenous by construction, also have some shortcomings. For example, the statutory corporate tax rate does not take into account the effects on the tax burden of investment incentives and tax relief related to financing arrangements, and may thus reflect only imperfectly the actual rates paid by businesses. 
Table 5. Controlling for possible endogeneity ${ }^{1}$

The estimated empirical model is:

\begin{tabular}{|c|c|c|c|c|}
\hline Dependent Variable: Log GDP p.c. & (1) & (2) & (3) & (4) \\
\hline \multicolumn{5}{|l|}{ Baseline Model } \\
\hline Physical Capital & $\begin{array}{l}0.33^{* * *} \\
(0.04)\end{array}$ & $\begin{array}{l}0.23^{* * *} \\
(0.03)\end{array}$ & $\begin{array}{l}0.36 * * * \\
(0.04)\end{array}$ & $\begin{array}{l}0.19^{* * *} \\
(0.05)\end{array}$ \\
\hline Human Capital & $\begin{array}{l}1.21^{* * *} \\
(0.09)\end{array}$ & $\begin{array}{l}2.01 \\
(0.08)\end{array}$ & $\begin{array}{l}1.19^{* * *} \\
(0.09)\end{array}$ & $\begin{array}{l}1.46^{* * *} \\
(0.13)\end{array}$ \\
\hline Population Growth & $\begin{array}{l}-0.09^{* * *} \\
(0.01)\end{array}$ & $\begin{array}{l}-0.06^{* * *} \\
(0.01)\end{array}$ & $\begin{array}{l}-0.09^{* * *} \\
(0.01)\end{array}$ & $\begin{array}{l}-0.10^{* * *} \\
(0.01)\end{array}$ \\
\hline \multicolumn{5}{|l|}{ Control variable } \\
\hline $\begin{array}{l}\text { Overall Tax Burden } \\
\text { (Total revenues / GDP) }\end{array}$ & $\begin{array}{l}-0.35^{* * *} \\
(0.05)\end{array}$ & $\begin{array}{l}-0.17^{* * *} \\
(0.03)\end{array}$ & $\begin{array}{l}-0.33^{* * *} \\
(0.06)\end{array}$ & $\begin{array}{r}0.01 \\
(0.04)\end{array}$ \\
\hline \multicolumn{5}{|l|}{ Tax structure variables } \\
\hline $\begin{array}{l}\text { Share of Income Taxes in Total Taxes } \\
\text { (corrected for business cycle) }\end{array}$ & $\begin{array}{l}-0.82^{* * *} \\
(0.13)\end{array}$ & $\begin{array}{l}-0.27^{* *} \\
(0.10)\end{array}$ & $\begin{array}{l}-0.90^{* * *} \\
(0.15)\end{array}$ & \\
\hline $\begin{array}{l}\text { Share of Corporate Income Taxes } \\
\text { in Income Taxes (corrected for bus. cycle) }\end{array}$ & & $\begin{array}{l}-0.60^{* * *} \\
(0.07)\end{array}$ & & \\
\hline $\begin{array}{l}\text { Share of Corporate Income Taxes } \\
\text { in Income Taxes (instrumented) }\end{array}$ & & & $\begin{array}{l}-0.36 * * \\
(0.17)\end{array}$ & \\
\hline $\begin{array}{l}\text { Income Tax Rate } \\
\text { (weighted average) }\end{array}$ & & & & $\begin{array}{l}-0.01^{* * *} \\
(0.00)\end{array}$ \\
\hline $\begin{array}{l}\text { Corporate Tax Rate } \\
\text { (relative to income tax rate) }\end{array}$ & & & & $\begin{array}{l}-0.12^{* * *} \\
(0.02)\end{array}$ \\
\hline
\end{tabular}

\begin{tabular}{lllll}
\hline Observations & 598 & 589 & 586 & 310
\end{tabular}

1. In the estimated model, $y$ refers to output per capita, $s_{k}$ to the investment rate into physical capital, $h$ to human capital, $n$ to the population growth rate, respectively. The vector $V$ contains a set of policy variables. All equations include short-run dynamics, country-specific intercepts and country-specific time controls. Standard errors are in brackets. *: significant at $10 \%$ level; ${ }^{* *}$ at $5 \%$ level; ${ }^{* \star *}$ at $1 \%$ level.

\section{Conclusions}

45. This paper examines the relationship between tax structures and economic growth by entering indicators of the tax structure into a set of panel growth regressions for 21 OECD countries, in which both the accumulation of physical and human capital are accounted for. Rather than taking time averages, the analysis is based on annual data for 1971-2004, using an Error-Correction specification to model the short term dynamics explicitly. This setting also allows to control for unobserved fixed effects at the country level.

46. The results of the analysis suggest that income taxes are generally associated with lower economic growth than taxes on consumption and property. More precisely, the findings allow the establishment of a ranking of tax instruments with respect to their relationship to economic growth. Property taxes, and particularly recurrent taxes on immovable property, seem to be the most growthfriendly, followed immediately by consumption taxes. Personal income taxes seem to be significantly inferior, and corporate income taxes have the most negative effects on GDP per capita. There is also evidence of a negative relationship between the progressivity of personal income taxes and growth. All of 
the results are robust to a number of different specifications, including controlling for other determinants of economic growth and instrumenting tax indicators.

47. Two caveats apply when drawing policy conclusions from the analysis in this paper: Firstly, it should be noted that this paper analyses the effects of different taxes on economic growth, which may not be the only objective of tax policy design. The distributional effects of different taxes - an analysis of which is beyond the scope of this paper - may also influence tax policy design, so that one should not blindly equate growth-friendly with politically desirable. In some cases, there may be trade-offs between different policy objectives, although in many cases such a trade-off does not exist. All this said, economic growth remains the precondition for the improvement of material living standards, and taxation is not the only policy lever available to advance distributional objectives. Secondly, any empirical insight generated from cross-country macro data only reveals a picture that is true on average. Under specific circumstances in specific country cases, there may be reasons to expect deviations from the general patterns presented here, and to assume different effects of certain tax instruments. Such cases could arise, for example, where countries already rely very heavily on one of the tax instruments identified here, so as to make them significant outliers from the sample average. A closer look at the specific situation of a given country is therefore needed before making policy recommendations on the basis of the empirical analysis presented here. For most cases, however, tax reforms towards property and consumption taxes, and especially away from corporate taxes, are likely to enhance the prospects for economic growth. 


\section{APPENDIX 1: DATA SOURCES AND DEFINITIONS}

48. Basic data on GDP, working age population, gross fixed capital formation, general government current nominal tax and non-tax revenues, direct and indirect taxes and imports and exports are from the OECD Annual National Accounts Data Base (ANA). Purchasing Power Parity benchmarks for 1995 are from the OECD Statistics Department. In the case of Norway, data refer to the mainland economy. Data on Research and Development (R\&D) are from the OECD Main Science and Technology Indicators (MSTI) database. A few missing observations were obtained by interpolation. Information on tax revenues comes from the 2006 edition of the "OECD Revenue Statistics".

49. The variables used in the regression analysis are defined as follows:

- GDP per capita: Real GDP per head of population aged 15-64 years expressed in 1995 Purchasing Power Parities (PPP) and in logs.

- Convergence variable (ln $\left.y_{-1}\right)$ : Lagged real GDP per head of population aged 15-64 years, in PPP, in logs.

- $\quad$ Physical capital accumulation $\left(s^{K}\right)$ : The propensity to accumulate physical capital is proxied by the ratio of non-residential gross fixed capital formation to GDP.

- Population growth (n): Growth rate of the population aged 15-64 years in percent.

- Stock of human capital (ln h): proxied by the average number of years of schooling of the population from 25 to 64 years of age, and taken from Arnold et al. (2007). This is an updated measure constructed on the basis of information from De la Fuente and Doménech (2000) and from various issues of the OECD publication "Education at a Glance". Three educational groups were considered: below upper secondary education (ISCED 0 to ISCED 2); upper secondary education (ISCED 3); and tertiary education (ISCED 5 to ISCED 7). For each of these three groups, information on the average years of schooling and the fraction of the working age population falling into each of the three groups were used to calculate the average years of education of the entire working age population as a weighted average. Data on educational attainment up to the early 1980s are interpolated from five-year observations from De la Fuente and Doménech (2000), while later observations are from matched OECD sources. Given that additions to human capital are measured when a degree is completed rather than at the time that the resulting skills are put to productive use, this variable is lagged on period.

- Overall tax burden: the ratio of general government current nominal tax revenues in nominal GDP

50. Tax indicators used in Tables 2 to 4: Expressed as the share of tax revenues from the respective categories in general government current nominal tax revenues. The respective categories are indicated below in reference to the OECD classification of taxes (as defined in the OECD Revenue Statistics).

- Income taxes: This includes categories 1000, 2000 (social security contributions) and 3000 (payroll taxes) of the OECD classification of taxes.

- Personal income taxes: This includes categories 1100, 2000 (social security contributions) and 3000 (payroll taxes) of the OECD classification of taxes. 
- Corporate income taxes: This includes category 1200 of the OECD classification of taxes.

- Consumption and property taxes: This includes category 4000, 5000 and 6000 of the OECD classification of taxes.

- Consumption taxes excluding property taxes: This includes category 5000 and 6000 of the OECD classification of taxes.

- Property taxes: This includes category 4000 of the OECD classification of taxes.

- Property taxes: Recurrent Taxes on Immovable Property: This includes category 4100 of the OECD classification of taxes. Other recurrent property taxes (category 4600, a very small position that makes up less than $0.01 \%$ of property taxes on average) have also been grouped with this category.

- Property taxes: Other Property Taxes: This includes categories 4200 to 4500 of the OECD classification of taxes, in other words all property taxes that are not contained in "Recurrent Taxes on Immovable Property".

51. Tax indicators used in Table 5:

- Income tax rate: obtained as a weighted average of the tax rate on corporate and labour income. The weights are obtained as country-specific time averages of the shares of corporate profits (corporate tax) and labour compensation (labour income tax) in total GDP.

- The statutory corporate tax rates: the ratio between the average corporate tax rate and the overall average income tax rate as defined above. Local taxes (or the average across regions) are included where they exist. Any supplementary taxes are included only if they apply generally.

52. Other controls:

- Inflation: the rate of growth of the private final consumption deflator

- Inflation volatility: the standard deviation of the rate of growth in private final consumption deflator - estimated over a three-year period.

- $\quad$ Research \& Development: gross domestic expenditure on civil R\&D as a percentage of GDP.

- Trade Openness: the sum of exports and imports of goods and services as a share of GDP, expressed in log. This variable has been adjusted for country size by regressing it on the log of the population size and taking the residuals of this regression. The resulting variable measures the part of trade openness that is not explained by mere differences in size across countries. 


\section{APPENDIX 2: THE BASELINE GROWTH SPECIFICATION}

53. Table 6 presents the results from the baseline growth regressions before the inclusion of taxes. In the first column, presented for illustrative purposes, time effects are not controlled for at all. In this specification, the Hausman test of long-run homogeneity of coefficients is rejected. However, this homogeneity test cannot be rejected once country-specific time effects are controlled for in the other two specifications (Columns 2 and 3). Controlling for country-specific time influences is therefore necessary to avoid confusing heterogeneous trends across countries with heterogeneity in the elasticities of the long-run explanatory variables.

54. All specifications suggest a (conditional) process of convergence-i.e. the lagged level of GDP per capita is negatively signed and statistically significant. Moreover, in all specifications, the coefficients on both physical and human capital appear with the expected sign and are highly significant. There is, however, some variability in the estimated coefficients depending on whether different forms of controls for time influences are chosen. Given the evidence of non-linear patterns in the overall growth trends over the last 35 years, the non-linear specification presented in Column (3) is considered the preferred specification and retained in the subsequent analysis.

Table 6. Baseline growth regressions ${ }^{1}$

\begin{tabular}{|c|c|c|c|}
\hline Dependent Variable: Log GDP p.c. & (1) & (2) & (3) \\
\hline \multicolumn{4}{|l|}{ Baseline Model } \\
\hline Physical Capital & $\begin{array}{l}0.70 \text { *** } \\
(0.14)\end{array}$ & $\begin{array}{l}0.31 \text { *** } \\
(0.03)\end{array}$ & $\begin{array}{l}0.19^{* * *} \\
(0.04)\end{array}$ \\
\hline Human Capital & $\begin{array}{l}1.09^{* * *} \\
(0.14)\end{array}$ & $\begin{array}{l}0.78^{\text {*** }} \\
(0.17)\end{array}$ & $\begin{array}{l}0.99^{* * *} \\
(0.11)\end{array}$ \\
\hline Population Growth & $\begin{array}{l}-0.26 \text { *** } \\
(0.04)\end{array}$ & $\begin{array}{l}-0.06^{* * *} \\
(0.01)\end{array}$ & $\begin{array}{l}-0.05^{* * *} \\
(0.01)\end{array}$ \\
\hline Convergence coefficient & $\begin{array}{l}-0.04 \text { *** } \\
(0.01)\end{array}$ & $\begin{array}{l}-0.21 \text { *** } \\
(0.03)\end{array}$ & $\begin{array}{l}-0.30^{* * *} \\
(0.04)\end{array}$ \\
\hline Observations & 699 & 699 & 699 \\
\hline Time Controls & None & Linear & Non-linear \\
\hline Hausman Test for PMG & 0.03 & 0.52 & 0.18 \\
\hline \multicolumn{4}{|c|}{$\begin{array}{l}\text { 1. In the estimated model, } y \text { refers to output per capita, } s_{k} \text { to the investment rate into physical } \\
\text { capital, } h \text { to human capital, } n \text { to the population growth rate, respectively. All equations include } \\
\text { short-run dynamics, country-specific intercepts and with the exception of column } 1 \text {, country-specific } \\
\text { time controls. Standard errors are in brackets. *: significant at } 10 \% \text { level; }{ }^{* *} \text { at } 5 \% \text { level; }{ }^{* *} \text { at } 1 \% \\
\text { level. }\end{array}$} \\
\hline
\end{tabular}

55. The three baseline specifications indicate coefficients for physical capital that are broadly consistent with the existing empirical literature: a 1 percentage point increase in the investment share (corresponding to a rise in investment by about 5\%) brings about an increase in steady state GDP per capita of about $0.7-1.1 \%$. The coefficients on human capital suggest relatively high returns to 
education: one extra year of average education (corresponding to a rise in human capital by about 9\%) would lead to an average increase in steady-state output per capita by about $5-7 \%$. These values tend to be higher than those generally obtained in large country sample regressions (e.g. Benhabib and Spiegel, 1994; Barro and Sala-i-Martin, 1995), ${ }^{15}$ but fairly consistent with those recently obtained by studies focusing on OECD countries (see Bassanini and Scarpetta, 2001; de La Fuente and Domenech, 2006; Cohen and Soto 2001; Krueger and Lindhal, 2001). ${ }^{16}$ They are also broadly consistent with estimated returns to schooling in the microeconomic literature (see Psacharopoulos and Patrinos, 2002).

56. A number of robustness checks have been run to test these baseline specifications. Given the error-correction property of the PMG estimator used here, it is important to check that the residuals from the long-run equation are stationary to avoid spurious regressions. The errors of the regression equation have been tested for non-stationarity using panel unit root test based on Im et al. (2003). Non-stationarity of the residuals was rejected at the $1 \%$ level. Moreover, the fact that the estimated coefficient on the convergence term is always highly significant also confirms that there is indeed a long-run relationship between the variables in the estimations. Finally, the results have also been checked for robustness with respect to different lag structures. This has been found to have no significant influence on the results obtained here.

15. This is likely to be due to the better quality of the proxy for human capital for the OECD countries.

16. Using the same econometric approach as in this paper but a shorter sample period, Bassanini and Scarpetta (2001) found the elasticity of output with respect to years of schooling to range between 0.4 and 0.7 ; de la Fuente and Domenech (2006), using different schooling datasets and different production functions, found that the elasticity was invariably above 0.6 . 


\section{REFERENCES}

Agell, J.; H. Ohlsson and P. Thoursie (2006), "Growth Effects of Government Expenditure and Taxation in Rich Countries: A Comment”, European Economic Review 50(1): 211-218

Aghion, P. and P. Howitt (2006), “Appropriate Growth Policy: A Unifying Framework”, Journal of the European Economic Association 4 (April-May 2006): 269-314.

Arnold, J.; A. Bassanini and S. Scarpetta (2007), "Solow or Lucas? Testing Growth Models Using Panel Data from OECD Countries". OECD Economics Department Working Papers No. 592.

Barro, R.J. 1989), “A Cross-Country Study of Growth, Saving, and Government”, National Bureau of Economic Research Working Paper No. 2855.

Barro, R. (1991), "Economic Growth in a Cross-Section of Countries", Quarterly Journal of Economics 104, pp. 407-444.

Barro, R. and X. Sala-i-Martin (1992), “Convergence”. Journal of Political Economy, 100(21), pp. 223251.

Barro, R. and X. Sala-i-Martin (1995), “Economic Growth”, McGraw-Hill, New York, NY.

Bassanini, A. and S. Scarpetta (2001), "Does Human Capital Matter for Growth in OECD Countries?", OECD Economics Department Working Papers No. 282.

Benhabib, J., and M.M. Spiegel (1994), "The Role of Human Capital in Economic Development: Evidence from Aggregate Cross-Country Data”, Journal of Monetary Economics 34, pp. 143-173.

Bleaney, M.F.; N. Gemmell and R. Kneller (2001), "Testing the Endogenous Growth Model: Public Expenditure, Taxation and Growth Over the Long-Run", Canadian Journal of Economics, Vol. 34(1), pp. 36-57.

Boulhol, H.; A. de Serres and M. Molnar (2008), "The Contribution of Economic Geography to GDP Per Capita", OECD Economics Department Working Papers No.602.

Caselli, F., G. Esquivel and F. Lefort (1996), "Reopening the Convergente Debate: A New Look at the Cross Country Growth Empirics", Journal of Economic Growth 1, pp. 363-389.

Cellini, R. (1997), "Implication of Solow's Growth Model in the Presence of a Stochastic Steady-State", Journal of Macroeconomics, 19, pp. 135-153.

Cohen, D. and M. Soto (2001), "Growth and Human Capital: Good Data, Good Results", CEPR Discussion Papers 3025.

De la Fuente, A. and R. Domenech (2006), 'Human Capital in Growth Regressions: How Much Difference Does Data Quality Make?', Journal of the European Economic Association, 4(1), pp. 1-36. 
Duval, R., J. Elmeskov and L. Vogel (2007), "Structural Policies and Economic Resilience to Shocks", OECD Economics Department Working Papers No. 567

European Commission Services/DG TAXUD (2006), "Macroeconomic Effects of a Shift from Direct to Indirect Taxation: A Simulation for 15 EU Member States", Note presented at the 72nd Meeting of the OECD Working Party No.2 on Tax Policy Analysis and Tax Statistics, Paris, 14-16 Nov. 2006.

Gemmell, N., R. Kneller and I. Sanz (2006), "Fiscal Policy Impacts on Growth in the OECD: Are They Long- or Short-Term?", Mimeo, University of Nottingham 2006.

Gentry, W.M., and R.G. Hubbard (2000), "Tax Policy and Entrepreneurial Entry", American Economic Review, American Economic Association, Vol. 90(2), pp. 283-287.

Hammond, P.J. and A. Rodriguez-Clare (1993) “On Endogenizing Long-Run Growth. Econometrica 52 (3): pp. 761-765.

Im, Kyung So, M. Hashem Pesaran, Yongcheol Shin (2003), "Testing for Unit Roots in Heterogeneous Panels", Journal of Econometrics, Vol. 115, pp. 53-74.

Islam, N. (1995), "Growth Empirics: A Panel Data Approach”, Quarterly Journal of Economics, Vol. 110, No. 4, pp. 1127-1170.

Johansson, A.; Heady, C.; Arnold, J.; Brys, B. and L Vartia (2008), “Tax and Economic Growth", OECD Economics Department Working Papers No. 621.

Kneller, R., M.F. Bleaney, and N. Gemmell (1999), "Fiscal Policy and Growth: Evidence from OECD Countries", Journal of Public Economics, 74, pp. 171-190.

Krueger, A.B. and M. Lindahl (2001), "Education for Growth: Why and for Whom?”, Journal of Economic Literature, American Economic Association, Vol. 39(4), pp. 1101-1136.

Lee, K., M.H. Pesaran and R. Smith (1997), "Growth and Convergence in a Multi-Country Empirical Stochastic Solow Model”, Journal of Applied Econometrics, Vol. 12, Issue 4, pp. 357-392.

Lucas, R.E. (1988), “On the Mechanics of Economic Development”, Journal of Monetary Economics, 22, pp. 3-42.

Mankiw, N.G., D. Romer and D.N. Weil (1992), "A Contribution to the Empirics of Economic Growth", The Quarterly Journal of Economics, Vol. 107, No. 2. (May, 1992), pp. 407-437.

Myles, G. (2008), "Economic Growth and the Role of Taxation", report for the $O E C D$, available at http://www.people.ex.ac.uk/gdmyles/papers/pdfs/OECDfin.pdf

OECD (2003), "The Sources of Economic Growth in OECD Countries", Paris.

Pesaran, M. Hashem, Yongcheol Shin and R.P. Smith (1999), "Pooled Mean Group Estimation of Dynamic Heterogeneous Panels", Journal of the American Statistical Association, Vol. 94, No. 446, pp. 621-634

Psacharopoulos, G. and H.A. Patrinos (2002), "Returns to Investment in Education: A Further Update", World Bank, Policy Research Working Paper Series 2881. 
Romer, P.M. (1990), “Endogenous Technical Change”, Journal of Political Economy, Vol. 98, No. 5, Part 2, pp. 71-102.

Schwellnus, C. and J. Arnold (2008), "Do Corporate Taxes Reduce Productivity and Investment at the Firm Level? Cross-country Evidence from the Amadeus Dataset", OECD Economics Department Working Papers, forthcoming.

Solow, R.M. (1957), "Technological Change and the Aggregate Production Function", Review of Economics and Statistics, Vol. 39, No. 3, pp. 312-320.

Swan, T.W. (1956), "Economic Growth and Capital Accumulation", Economic Record, Vol. 32 (2), pp. 334-61.

Vartia, L. (2008), "How Do Taxes Affect Investment and Productivity? - Industry Level Analysis of OECD Countries", OECD Economics Department Working Papers, forthcoming. 


\section{WORKING PAPERS}

The full series of Economics Department Working Papers can be consulted at www.oecd.org/eco/Working_Papers/

642. Accounting for one-off operations when assessing underlying fiscal positions

(October 2008) Isabelle Joumard, Makoto Minegishi, Christophe André, Chantal Nicq and Robert Price

641. Do corporate taxes reduce productivity and investment at the firm level? Cross-country evidence from the Amadeus dataset

(October 2008) Cyrille Schwellnus and Jens Arnold

640. The challenge of rapidly improving transport infrastructure in Poland

(September 2008) Rafal Kierzenkowski

639. Bridging the housing gap in Poland

(September 2008), Rafal Kierzenkowski

638. Improving the business and investment climate in Indonesia (September 2008), Diego Moccero

637. Growth performance and policy challenges

(September 2008), Luiz de Mello

636. A taxonomy of instruments to reduce greenhouse gas emissions and their interactions

(September 2008), Romain Duval

635. Quantifying the effect of financial conditions on US activity

(September 2008) Stéphanie Guichard and David Turner

634. Have long-term financial trends changed the transmission of monetary policy

(September 2008), Stéphanie Guichard and David Turner

633. Raising education achievement and breaking the cycle of inequality in the United Kingdom (August 2008) Anne-Marie Brook

632. The euro changeover in the Slovak Republic: implications for inflation and interest rates (August 2008) Felix Hüfner and Isabell Koske

631. Tax reform for efficiency and fairness in Canada (August 2008) Alexandra Bibbee

630. Reforming the Polish Tax System to Improve its Efficiency

(August 2008) Alain de Serres

629. Modernising Canada's Agriculture Policies (August 2008) Peter Jarrett and Shuji Kobayakawa

628. Recent trends and structural breaks in US and EU15 labour productivity growth (August 2008) Laure Turner and Hervé Boulhol 
627. Health Status Determinants: Lifestyle, Enviroment, Health Care Resources and Efficiency (August 2008) Isabelle Joumard, Christophe André, Chantal Nicq and Olivier Chatal

626. Market Mechanisms in Public Service Provision (August 2008) Hansjörg Blöchliger

625. Improving human capital formation in India (July 2008) Sean M. Dougherty and Richard Herd

624. Labour regulation and employment dynamics at the state level in India (July 2008) Sean M. Dougherty

623. India's growth pattern and obstacles to higher growth (July 2008) Sean M. Dougherty, Richard. Herd, Thomas. Chalaux and Abdul. Erumban

622. Reaping the benefits of stronger competition in network industries in Germany (July 2008) Nicola Brandt

621. The Usefulness of Output Gaps for Policy Analysis (July 2008) Isabell Koske and Nigel Pain

620. Taxation and Economic Growth (July 2008) Åsa Johansson, Christopher Heady, Jens Arnold, Bert Brys and Laura Vartia

619. Coping with labour shortages: How to bring outsiders back to the labour market (July 2008) Ekkehard Ernst

618. Achieving sustainability of the energy sector in Canada (June 2008) Annabelle Mourougane

617. The Dutch tax-benefit system and life-cycle employment. Outcomes and reform options (June 2008) Ekkehard Ernst and Timo Teuber

616. Regulation, Allocative Efficiency and Productivity in OECD Countries: Industry and Firm-Level Evidence

(May 2008) Jens Arnold, Giuseppe. Nicoletti, and Stefano Scarpetta

615. Public social spending in Korea in the context of rapid population ageing (May 2008) Randall S. Jones

614. Enhancing the globalisation of Korea (May 2008) Randall S. Jones and Taesik Yoon

613. Reforming housing and regional policies in Korea (May 2008) Randall S. Jones and Tadashi Yokoyama

612. Moving towards more sustainable healthcare financing in Germany (May 2008) N. Brandt

611. Improving education outcomes in Germany (May 2008) David Carey 